\title{
How Marketing Communications Correlates With Business Performance
}

Damijan Mumel, (Email: damijan.mumel@uni-mb.si), University of Maribor, Slovenia Nina Hocevar, (Email: nina1.hocevar@uni-mb.si), University of Maribor, Slovenia Boris Snoj, (Email: boris.snoj@uni-mb.si), University of Maribor, Slovenia

\begin{abstract}
Companies use different marketing activities to communicate with the environment. These decisions are often a result of past experiences, habits or a certain influences. Measuring the efficiency of a communication mix as well as analyzing the effect of using a specific marketing communication activity on different business performance determinants are usually neglected. This paper might contribute to this problem as it focuses on the correlation between marketing communication activities and the business performance of a company through two aspects: a) the frequency of using a specific marketing communication activity and its correlation to business performance determinants; $b$ ) the correlation between the number of marketing communication activities that a company uses and its business performance determinants. We found statistically significant relationships (positive and negative) among some variables. The results helped us interpret which activity a company should use in order to increase customer loyalty, which activity helps raise net profit, and how many marketing communication activities should a company employ to optimise business performance. With this, managers have obtained basic guidelines when building their marketing communication mix.
\end{abstract}

\section{INTRODUCTION}

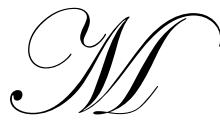

anagers in Slovenian SMEs (small and medium-sized enterprises; further companies) are aware that marketing communications is an important resource of their business performance (Snoj et al, 2001). In communicating with their environment, they use different marketing communication activities and tools (further on in this paper, we use the term "marketing communication activity" to refer to both the marketing communication activity and the marketing communication tool). The efficiency of their communication mix, as well as measuring the effect of marketing communications on business performance, is usually neglected.

There have been many papers analysing the correlation between certain marketing tools or activities and resultant business performance determinants. Some authors analyse the effects on sales (Assmus et al., 1984; Kapil and Shoemaker, 2004; MacInnis et al., 2002; Tellis and Weiss, 1995); many authors analyse the effects on customer satisfaction (Bendall-Lyon and Powers, 2003; Homburg and Stock, 2004; Kenneth, 2000; Jap, 2001; Lewis, 2004). There have been many authors who analyse the effectiveness of a certain marketing activity (Fitzgerald, 2004; Hart, 1992; Horsky, 1996; Kim, 2003; Srivasan and Anderson, 1998; Xueming and Naveen, 2001).

Lately there have been several papers analysing the relationship between integrated marketing communications and business performance (Low, 2000; Reid, 2003; Reid et al, 2001; Zahay et al., 2004), and the relationship between marketing orientation and business performance (Gray and Hooley, 2002; Guo, 2002; Konic, 2003; Matear et al., 2002; Pulendran et al., 2003; Snoj et al., 2001).

Although there are many papers, articles and contributions analyzing the correlation between marketing communication and business performance, we couldn't find any specific research that would focus on the correlation between: 
- $\quad$ the frequency of using a specific marketing communication activity and its correlation to business performance, and

- the number of marketing communication activities that a company uses and its business performance.

Results of this research are used for a better understanding of marketing communications and for further research in this field.

\section{RESEARCH QUESTIONS AND HYPOTHESIS FORMULATION}

From a literature review, authors could extract that there have been some papers analysing the correlation between marketing communication activities and business performance. Authors could find several papers analysing the correlation between marketing communications and sales; sales promotion and sales (Biyalogorsky and Naik, 2003; Kapil and Shoemaker, 2004; Srinivasan, 1998); advertising and sales (Jagpal, 1981; Luo and Donthu, 2001; MacInnis et al., 2002; Tellis and Weiss, 1995); and personal selling and sales (Dong-Gil Ko and Dennis, 2004; Frankwick et al., 2001; Homburg and Stock, 2004).

Some papers were focused on analysing the correlation between marketing communications and profit or profitability (Byung-Do et al., 2001; Kenneth et al., 2000; Reid, 2003; Reid et al., 2001; Srinivasan, 1998). BendallLyon and Powers (2003), Boulding et al. (1994), Frankwick et al. (2001), Lewis (2004) and Sunil et al. (2004) analysed the relationship between marketing communications and customer retention, customer loyalty and satisfaction.

The authors formulated and tested four research hypotheses, as shown in Figure 1.

Figure 1: Research Model

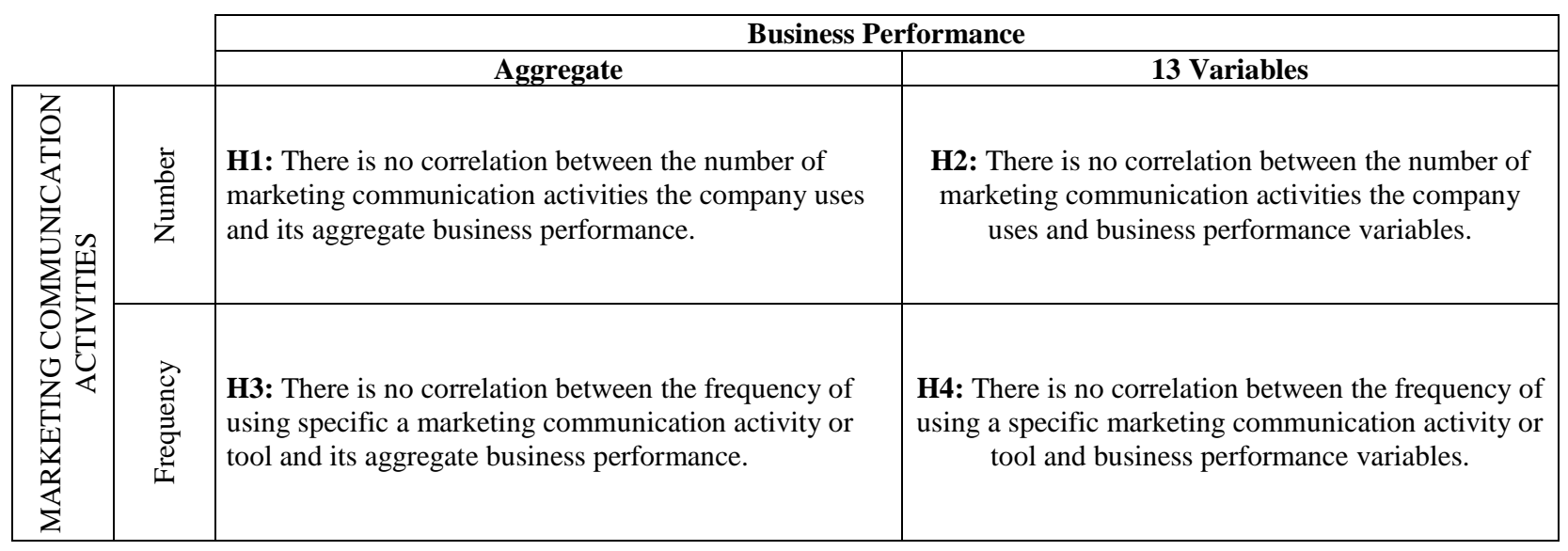

\section{METHODOLOGY AND DATA COLLECTION}

First, variables of the business performance of a company were defined, and the data concerning business performance were collected. Although a basic theory says that a company is successful when achieving its goals, there have been many attempts to set clearer criteria for measuring business performance. In our research, both subjective and objective data were used, some of them financial and some non-financial.

As Konic (2003) suggested, the aggregate business performance of a company is defined through 13 variables: net sales, net sales growth index, net profit margin, return on equity, net return on assets, net profit/loss per employee, net business result for the accounting period, customer loyalty, achieved profit vs. planned, achieved net 
return on investment vs. planned, achieved net sales vs. planned, achieved market share vs. planned, and achieved employee loyalty vs. planned.

The aggregate business performance of a company was calculated as the sum of the standardized values of all these 13 business performance variables.

Second, the authors explored which and how often a certain marketing communication activity was used by the companies. Based on the findings from the literature (Belch and Belch, 1998; Fill, 2002; Hocevar, 2004; Snoj et al., 2001), the list of 21 different marketing communication activities included: printed advertisements in newspapers, radio commercials, press conferences, price reductions, direct mail, direct e-mail, contests, newsletters, sponsorships, leaflets, press releases, events, internet pages, pamphlets, business databases (Kompass), internet banners, postponed payments, donations, trade shows, personal presentations and TV commercials.

Data about marketing communication activities and some financial data of targeted companies were obtained through telephone interviews with small business managers. The financial data of those companies was obtained through the web portal GVIN Slovenian business intelligence (www.gvin.com).

The population consisted of limited liability companies registered in Slovenia, which are registered for language teaching (80.422 NACE classifications) and which had more than one and less than 50 employees. There are 44 companies in Slovenia matching these criteria, and we obtained data from 37 of them.

\section{RESULTS}

\section{The Number Of Marketing Communication Activities And Aggregate Business Performance:}

Marketing communication activities are all the activities that a company uses in order to communicate with its different publics (customers, suppliers, employees, the government). Managers were asked to mark which marketing communication activities the company uses. From their answers, we generated the variable 'number of marketing communication activities the company uses.'

Based on the results, it was concluded that the highest percentage of the companies use nine different marketing communication activities; modus is 9 , mean is 9.4 (Figure 2).

Figure 2: The Number Of Marketing Communication Activities Used By The Companies.

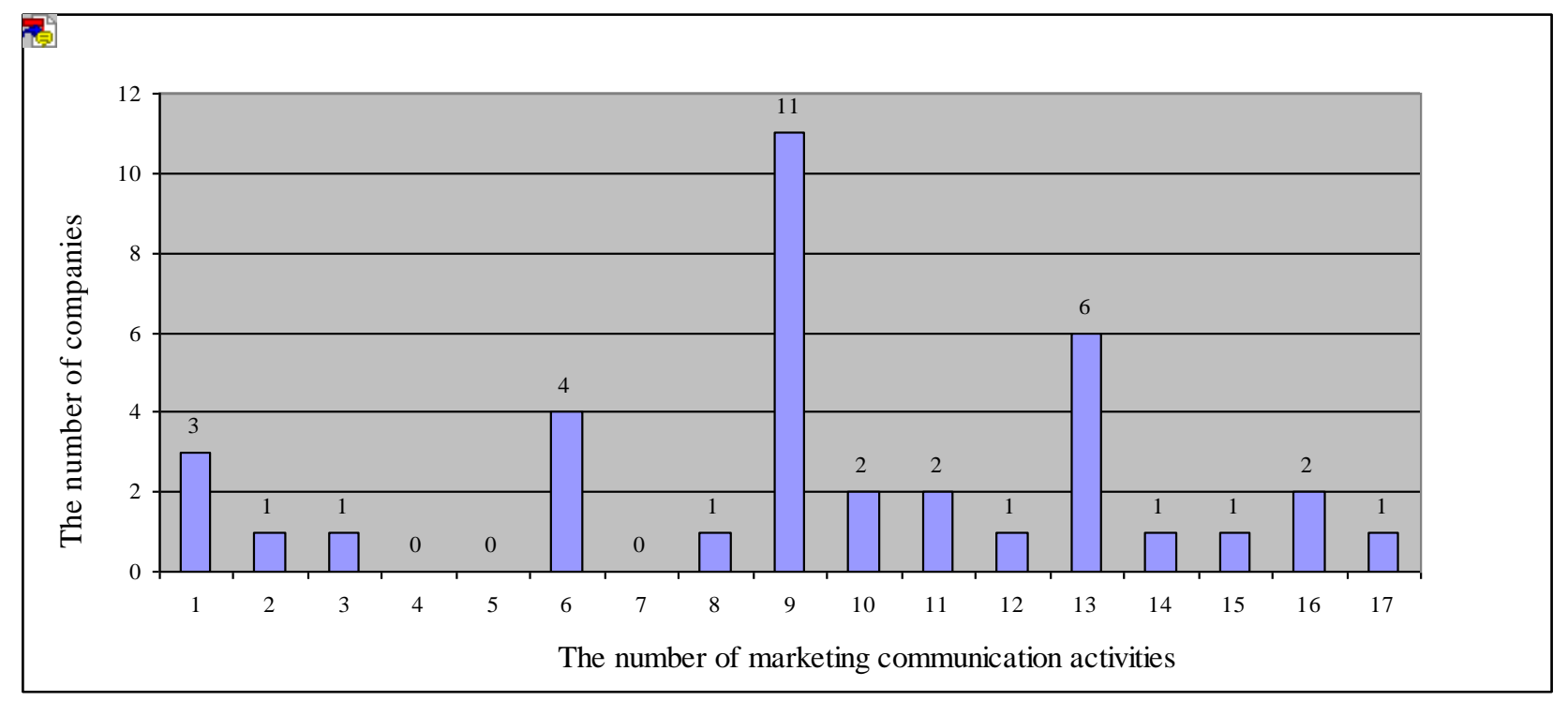


After gaining data about business performance and learning how many marketing communication activities the companies use, a Pearson correlation analysis between these two variables was conducted. We can conclude that there is no significant correlation between the number of marketing communication activities that a company uses and the aggregate business performance of a company $(r=-0,211, p=0,211)$.

Subsequently, this means that the hypothesis H1. "There is no correlation between the number of marketing communication activities the company uses and its aggregate business performance," was accepted.

\section{The Number Of Marketing Communication Activities And Business Performance Variables}

In order to deepen the correlation analysis, the relationship between the number of marketing communication activities a company uses and all 13 variables of business performance was analysed with a Pearson correlation (Table 2).

Table 2: The Relationship Between The Number Of Marketing Communication Activities A Company Uses And Business Performance Variables.

\begin{tabular}{|l|c|c|}
\hline \multirow{2}{*}{} & \multicolumn{2}{|c|}{ Number of marketing communication activities } \\
\cline { 2 - 3 } & Pearson Correlation & 0,008 \\
\hline Net sales & $0,428^{* *}$ & 0,025 \\
\hline Customer loyalty & $-0,367^{*}$ & 0,066 \\
\hline Achieved employee loyalty vs. planned & $-0,306$ & 0,080 \\
\hline Net profit margin & $-0,292$ & 0,084 \\
\hline Net profit/loss per employee & $-0,288$ & \\
\hline
\end{tabular}

**correlation is significant at the 0,01 level (2-tailed). *correlation is significant at the 0,05 level (2-tailed).

Based on the results from Table 2, the authors concluded that there is a significant correlation between the number of marketing communication activities a company uses and two business performance variables:

- $\quad$ net sales and

- customer loyalty.

The correlation between the number of marketing communication activities a company uses and net sales is significant: $\mathrm{p}=0,001$ and positive $\mathrm{r}=0,428$.

The correlation between the number of marketing communication activities of the analysed companies and customer loyalty is significant: $\mathrm{p}=0,05$ level (2-tailed) and negative $\mathrm{r}=-0,367$.

Therefore, the hypothesis H2, "There is no correlation between the number of marketing communication activities the company uses and business performance variables," was rejected.

There also exists a negative correlation between the number of marketing communication activities the company uses and:

- $\quad$ achieved employee loyalty vs. planned $(\mathrm{r}=-0,306, \mathrm{p}=0,06)$

- net profit margin ( $\mathrm{r}=-0,292, \mathrm{p}=0,08)$

- net profit/loss per employee $(\mathrm{r}=-0,288, \mathrm{p}=0,08)$ 


\section{The Frequency Of Using Certain Marketing Communication Activity And Aggregate Business Performance}

In order to find out which marketing communication activity shows the strongest correlation with the aggregate business performance of a company, the frequency of using certain marketing activities in one school year was explored.

On a seven-point scale, managers evaluated how often they use a specific marketing activity (we don't use this activity, once a year, twice a year, every three months, every two months, every month, every week).

When calculating the frequency of using a certain marketing communication activity, the following facts were taken into account. The nature of the language teaching in Slovenia is such that the majority of services are delivered during a 10-month school season, which is divided into two semesters; the first semester is from October to February, and the second from March to July. This is also reflected in their marketing communication activities. The highlights of marketing activities are at the beginning of each semester in September and February. One school year has 10 months, two semesters and 40 weeks.

The correlation between the frequency of using a specific marketing communication activity and aggregate business performance was analysed. Significant correlations are presented in Table 3.

Table 3: Significant Correlations Between The Frequency Of Using Specific Marketing Communication Activity And The Aggregate Business Performance Of A Company.

\begin{tabular}{|l|c|c|}
\hline \multirow{2}{*}{ Frequency Of Using Marketing Communication Activity } & \multicolumn{2}{|c|}{ Aggregate Business Performance } \\
\cline { 2 - 3 } & Pearson Correlation & 0,01 \\
\hline price reduction & $-0,41^{* *}$ & 0,02 \\
\hline printed advertisements in newspapers & $0,37^{*}$ & 0,03 \\
\hline sales contests & $-0,36^{*}$ & \\
\hline
\end{tabular}

**correlation is significant at the 0,01 level (2-tailed). *correlation is significant at the 0,05 level (2-tailed).

It was found that the marketing communication activity that correlates most with the business performance of a company is price reduction $(\mathrm{r}=-0,41, \mathrm{p}=0,01)$, followed by

- $\quad$ contests $(\mathrm{r}=-0,36, \mathrm{p}=0,05)$, and

- $\quad$ printed advertisements in newspapers $(\mathrm{r}=0,37, \mathrm{p}=0,05)$.

Therefore, the hypothesis H3, "There is no correlation between the frequency of using a specific marketing communication activity or tool and its aggregate business performance," was rejected.

Furthermore, we can say that there is a negative correlation between the aggregate business performance of a company and the frequency of using price reductions and contests as sales promotion tools. The analysis showed that the companies that tend to use price reductions and contests have a lower business performance rate than those who don't. For both, for price reductions as well as for sales contests, it was confirmed that the more often the company performs these activities, the lower is its business performance.

\section{The Frequency Of Using Certain Marketing Communication Activities And Business Performance Variables}

In the next step of the research, the correlation between the frequency of using marketing communication activities and all 13 variables of business performance was analyzed. The purpose of this analysis was to deepen the knowledge of the correlation between marketing communication activities and variables of business performance. Significantly, both positive and negative correlations between these two sets of variables were found. 
The strongest positive and negative correlations were found between frequency of using printed advertisements in newspaper and business performance variables. The strongest positive correlation was found with the net business result for accounting period $(r=0,85, p=0,01)$, followed by correlations with net sales $(r=0,62, p=0,01)$ and net return on assets $(\mathrm{r}=0,33, \mathrm{p}=0,05)$. The strongest negative correlation was between the frequency of using printed advertisements in newspaper and customer loyalty $(r=-0,62, p=0,01)$.

A clear picture of all significant correlations between marketing communication activities and business performance variables can be seen in Figure 1.

Based on these results, the hypothesis H4, "There is no correlation between the frequency of using a specific marketing communication activity or tool and business performance variables," was rejected.

Figure 1: Review Of Significant Correlations Between Business Performance Variables And The Frequency Of Using A Specific Marketing Communication Activity.

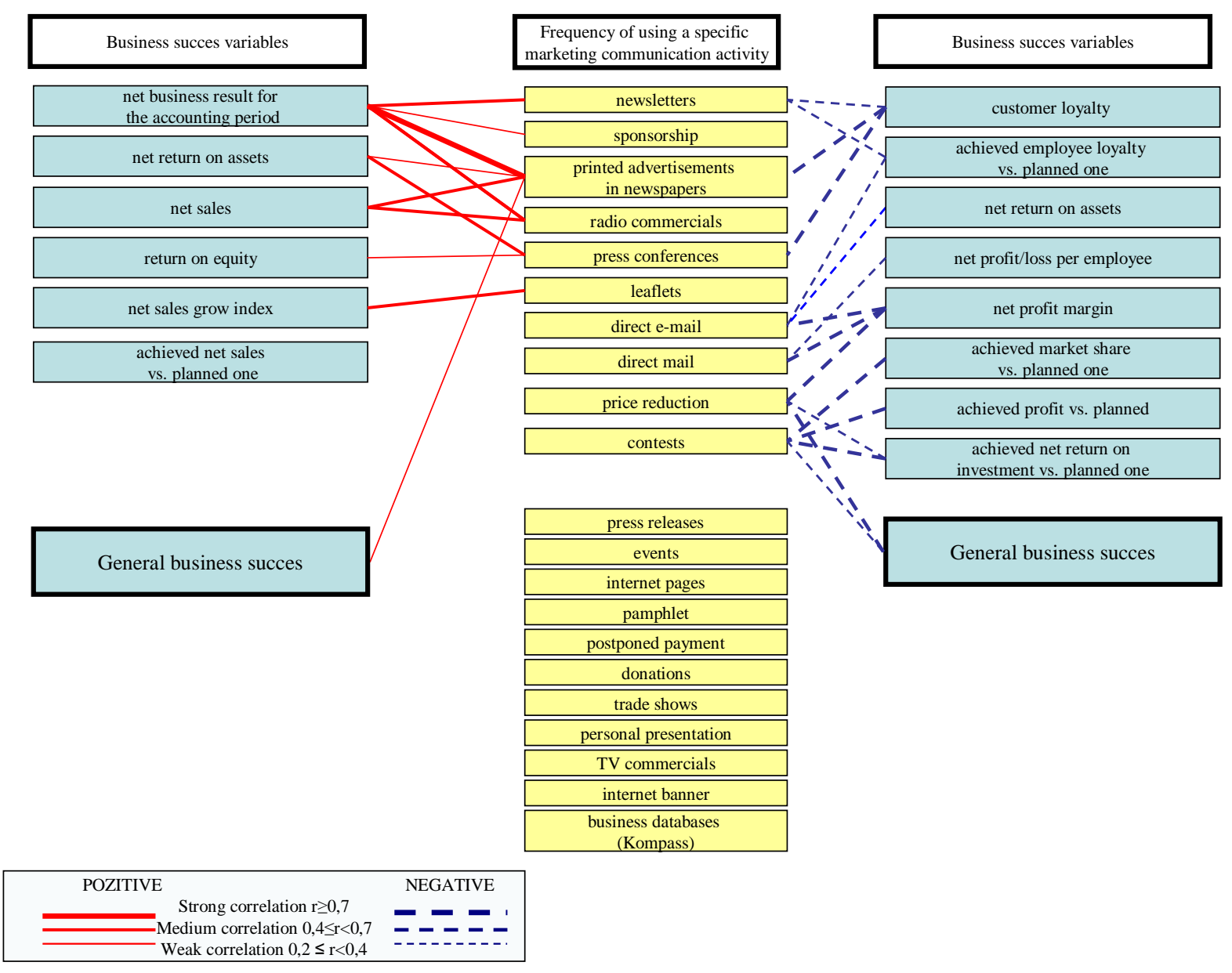


As a result of analyzing the correlations between the frequencies of using a specific marketing communication activity, the authors propose which marketing communication activity a company should use in order to improve a specific business performance variable.

\section{CONCLUSION}

From the literature review, the authors could extract that there have been some papers analysing the correlation between marketing communication activities and business performance, and with the present research, they wanted to demonstrate one of the possible approaches in analyzing this connection. Research revealed several correlations between the number of marketing communication activities the company uses, the frequency of their use and the business performance of companies offering language teaching in Slovenia.

Regarding the connection between the number of marketing communication activities the company uses and business performance results, it was revealed that although there is no correlation between the number of marketing communication activities and aggregate business performance, a correlation exists between the number of marketing communication activities and two business perfromance variables: net sales and customer loyalty. This could imply that a company cannot assume to raise business performance in general just by increasing the number of marketing communication activities, but it can increase certain business success indicators. The negative correlation between the number of marketing communication activities of analysed companies and customer loyalty implies that the companies which have more loyal customers use fewer marketing communication activities than those who don't, because they have already established a solid customer base. This is obviously not the case with the companies that use a wider communication mix.

The connection between the frequency of using certain marketing communication activities and business performance results indicates that the frequency of using certain marketing communication activities correlates with both aggregate business performance and separate business performance variables.

The frequency of using price reductions and contests as marketing communication activities shows the strongest negative correlation with aggregate business performance. On the other hand, the frequency of using printed advertisements in newspapers demonstrates the strongest positive correlation with aggregate business performance.

Regarding the correlation between business performance variables and the frequency of using a specific marketing communication activity, the results indicate several correlations. The frequency of using printed advertisements in newspapers as a marketing communication activity demonstrates the strongest correlations with separate business performance variables. Companies which are using printed advertisements in newspapers more frequently have demonstrated higher net business results for the accounting period, net sales and net return on assets, but lower customer loyalty.

\section{IMPLICATIONS}

The authors imply that the results could be used as a guideline when deciding about marketing communication activities for both companies involved in this research as well as all similar companies. Results of the research revealed that companies can influence their business performance results both by using a wider assortment of marketing communication activities and with frequent use of certain marketing communication activities.

According to the research, it is advisable to use as many marketing communication activities as companies can afford; however, the activities should be chosen on the basis of professional marketing management (research, data gathering, analysis, setting measurable objectives). When developing their marketing communication mix, managers of companies which are offering foreign language teaching should take into consideration the correlations between the frequency of using certain marketing communication activities and business performance variables.

The results of the research project imply that companies aspiring for better business performance should concentrate more on the frequency of using specific marketing communication activities and not so much on how 
many marketing communication activities they should use. There are two reasons for this. First, according to research, the frequency of using certain marketing communication activities correlates with the number of business performance variables, and this results in more options to improve certain business performance indicators. Second, it is much easier to adjust the frequency of use of marketing communication activities than to adjust the number of marketing communication activities the company uses.

Language-teaching companies should focus their marketing communication activities to advertising in newspapers, radio commercials, press conferences and newsletters, and not so much on price reductions and contests when forming a marketing communication mix.

\section{SUGGESTIONS FOR FUTURE RESEARCH}

The research was focused on business-to-customer and gave insight into how the use of a specific marketing communication activity reflects in business performance in a certain sector of the economy. Obtaining similar research within other industries using representative samples or even a population of companies in different countries would contribute to a better understanding of the relationship between marketing communication activities and business performance in different settings.

The results could be richer when including research variables that are closely connected to marketing communication activities, e.g. variables of IMC, management of marketing communication, etc.

The results and their possible interpretations give us a challenge in researching the relationship between marketing communication activities and the business performance of a company in a way that had not been previously explored.

\section{REFERENCES}

1. Belch, G. E. and Belch, M. A., Advertising and promotion: An integrated marketing communications perspective. Boston: Irwin/ McGraw-Hill. 1998.

2. Bendall-Lyon, D. and Powers T. L., The influence of mass communication and time on satisfaction and loyalty, Journal of Services marketing, Vol. 17, No.6, pp. 589-608, 2003.

3. Biyalogorsky, E. and Naik, P., Clicks and Mortar: The Effect of On-line Activities on Off-line Sales, Marketing Letters. Vol. 14, No. 1, pp. 21-30, 2003.

4. Boulding, W., Lee, E., and Staelin, R., Mastering the mix: Do advertising, promotion, and sales activities lead to differentiation? Journal of Marketing Research, Vol. 31, No. 2, pp. 159-172, 1994.

5. Byung-Do, K., Mengze, S., and Srinivasan, K., Reward Programs and Tacit Collusion Marketing Science, Vol. 20, Issue 2, pp. 99-121, 2001.

6. Dong-Gil, K. and Dennis, A. R., Sales force automation and sales performance: do experience and expertise matter? Journal of Personal Selling \& Sales Management, Vol. 24, No. 4, pp. 311-322, 2004.

7. Fill, Chris. Marketing communications. Contexts, Strategies and Applications. Essex: Pearson Education limited. 2002.

8. Frankwick, G. L., Porter, S., and Crosby, L. A., Dynamics of Relationship Selling: A Longitudinal Examination of Changes in Salesperson-customer Relationship Status, Journal of Personal Selling \& Sales Management, Vol. 21, No. 2, pp. 135-147, 2001.

9. Gray, B. and Hooley G. J., Market orientation and service firm performance - a research agenda, European Journal of Marketing, Vol. 36, No. 9/10, pp. 980 -988, 2002.

10. Guo, C., Market orientation and business performance. A framework for service organizations, European Journal of Marketing, Vol. 36, No. 9/10, pp. 1154 - 1163, 2002.

11. Hart, S. and Diamantopoulos, A., Marketing research activity and company performance: Evidence for Manufacturing Industry, European Journal of Marketing, Vol. 27, No. 5, pp. 54-72, 1992.

12. Hocevar, N., The correlation between marketing communication and business performance in language schools in Slovenia [Zveza med marketinskim komuniciranjem in poslovno uspesnostjo podjetij za poucevanje tujih jezikov.], Master thesis. Maribor: Faculty of Business and Economics. 2004. 
13. Homburg, C. and Stock, R.M., The Link Between Salespeople's Job Satisfaction and Customer Satisfaction in a Business-to-Business Context: A Dyadic Analysis, Academy of Marketing Science, Vol. 32, No. 2, pp. 144-159, 2004.

14. Horsky D. and Nelson, P., Evaluation of Sales Force Size and Productivity through Efficient Frontier Benchmarking, Marketing Science, Vol. 15, No. 4, pp. 301 - 320, 1996.

15. Jagpal S. H., Measuring Joint Advertising Effects in Multiproduct Firms, Journal of Advertising Research, Vol. 21, No. 1, pp. $65-69,1981$.

16. Kapil, B. and Shoemaker, R., The Effects of Free Sample Promotions on Incremental Brand Sales, Marketing Science, Vol. 23, No.3, pp 345-363, 2004.

17. Kenneth, B.I., Donthu, N., and Kennett, P. A., A Longitudinal Analysis of Satisfaction and Profitability, Journal of Business Research, Vol. 47, pp. 161-171, 2000.

18. Kim, H., Kim, W.G., and Jeong, A., The effect of consumer-based brand equity on firms' financial performance, Journal of Consumer Marketing, Vol.20, No 4., pp. 335-351, 2003.

19. Konic, M., Market orientation and business performance of small companies in Slovenia. [Trzna naravnanost in uspesnost malih podjetij v Sloveniji.], Master thesis. Ljubljana: Faculty of Economics. 2003.

20. Lewis, M., The Influence of Loyalty Programs and Short-Term Promotions on Customer Retention, Journal of Marketing Research, Vol. 41, pp. 281-292, 2004.

21. Low S. G., Correlates of Integrated Marketing Communications, Journal of Advertising Research, pp. 27-39, 2000.

22. MacInnis, D., Rao, J., Ambar, G., and Weiss, A. M., Assessing when increased media weight of real-world advertisements helps sales, Journal of Marketing Research, Vol. 39, pp. 391-407, 2002.

23. Matear, S., Osborne, P., Garett, T., and Grey, B.J., How does market orientation contribute to service firm performance? European Journal of Marketing, Vol. 36, No. 9/10, pp. 1058 - 1075, 2002.

24. Pulendran, S., Speed, R., and Widing, R. E. Marketing planning, market orientation and business performance European Journal of Marketing,. Vol. 37, No. 3/4, pp. 476 - 497, 2003.

25. Reid, M., IMC-performance relationship: further insight and evidence from the Australian marketplace, International Journal of Advertising, Vol. 22, No. 2, pp. 227-248, 2003.

26. Reid, M., Johnson, T., Ratcliffe, M., Skrip, K., and Wilson, J., Integrated marketing communications in the Australian and New Zealand wine industry, International Journal of Advertising, Vol. 20, No. 2, pp. 239262, 2001.

27. Snoj, B., Gabrijan, V., Mumel, D., Irsic, M., and Petermanec, Z., Market performance characteristics of Slovenian companies. [Znacilnosti trznega nastopa podjetij v Sloveniji.] Maribor: Faculty of business and economics. 2001.

28. Srinivasan, S. S. and Anderson, R.E., Concepts and strategy guidelines for designing value enhancing sales promotion, Journal of Product \& Brand Managemen, Vol.7, No.5, pp. 410-420, 1998.

29. Tellis, G. J. and Weiss, D. L. Does TV advertising really affect sales? The role of measures, models, and data aggregation. Journal of Advertising, Vol. 24, No. 3, pp. 1 -13, 1995.

30. Xueming, L. and Naveen, D., Benchmarking Advertising Efficiency, Journal of Advertising Research, Vol. 41, No. 6, pp. 7-18, 2001.

31. Zahay, D., Peltier, J., Schultz, D. E., and Griffin, A., The Role of Transactional versus Relational Data in IMC Programs: Bringing Customer Data Together Journal of Advertising Research, Vol. 44, No.1, pp 3-18, 2004. 
NOTES 